\title{
Proline-induced Germ-tube Formation in Candida albicans: Role of Proline Uptake and Nitrogen Metabolism
}

\author{
By ANN R. HOLMES AND M. G. SHEPHERD* \\ Experimental Oral Biology Unit, School of Dentistry, PO Box 647, Dunedin, New Zealand
}

(Received 11 May 1987; revised 29 June 1987)

\begin{abstract}
Proline-induced germ-tube formation and cell-cell aggregation in four strains of Candida albicans were completely inhibited when the $\mathrm{pH}$ of the medium was 5.0 or lower, whereas morphogenesis induced by $\mathrm{N}$-acetylglucosamine (GlcNAc) was unaffected even at $\mathrm{pH} 4.5$. The $\mathrm{pH}$ sensitivity of proline-induced germ-tube formation was not caused by a modulation of proline uptake, which was unchanged over the $\mathrm{pH}$ range $4 \cdot 5-6 \cdot 5$. The proline uptake system was specific, constitutive and subject to ammonium repression, and only one permease was detected, with a $K_{\mathrm{m}}$ of $179 \mu \mathrm{M}$. Cultures deprived of nitrogen in the presence of glucose were derepressed for proline uptake but the yeast-mycelial transition could not be mediated by either proline or GlcNAc. The inhibition of morphogenesis was reversed when the nitrogen starvation was relieved by the addition of ammonium ions, proline, or certain amino acids. These results indicate that the nitrogen status of the cells is critical for the morphogenesis of C. albicans.
\end{abstract}

\section{INTRODUCTION}

Candida albicans maintains a yeast morphology at temperatures below $34^{\circ} \mathrm{C}$. The transition to mycelial morphology requires incubation at higher temperatures and the presence of an inducer, such as serum, amino acids or $N$-acetylglucosamine (GlcNAc) (Shepherd et al., 1985). Land et al. (1975) and Dabrowa et al. (1976) both found that of the small number of amino acids and the imino acid proline that promoted filamentation, proline was the most effective. The complex defined medium devised by Lee et al. (1975) for growth of both the yeast and mycelial forms contains a number of amino acids and proline in addition to glucose, salts and biotin. Mitchell \& Soll (1979) showed that in this medium germ-tube formation is sensitive to external $\mathrm{pH}$, and Herman \& Soll (1984) have used $\mathrm{pH}$ regulation as a system to compare the properties of the yeast and mycelial forms of $C$. albicans. We have found that external $\mathrm{pH}$ also controls dimorphism in a simple buffered proline solution, whereas the response to another inducer of dimorphism, GlcNAc, is relatively insensitive to decreased $\mathrm{pH}$. The present study was undertaken to determine whether the $\mathrm{pH}$-sensitive event is related to proline uptake and metabolism.

Previously published work on the uptake of proline into C. albicans is contradictory. Dabrowa $\&$ Howard (1981) found that the uptake system was highly specific and not inducible, although uptake by mycelial cells was two to three times higher than that by yeast cells. In contrast, Jayakumar et al. (1979) concluded that uptake was both constitutive and inducible and not completely specific in that a number of amino acids partially inhibited uptake. In Saccharomyces cerevisiae two proline uptake systems have been described, neither of which is inducible (Lasko $\&$ Brandriss, 1981); in addition to a specific, high-affinity system $\left(K_{\mathrm{m}} 250 \mu \mathrm{M}\right)$ there is a lowaffinity system $\left(K_{\mathrm{m}} 13 \mathrm{mM}\right)$, probably the general amino-acid permease (GAP), which operates at high external concentrations of proline. Magaña-Schwenke et al. (1973) have also reported a specific high-affinity uptake system for imino acids in $S$. chevalieri, and showed that derepression operates under conditions of nitrogen starvation (Kuznar et al., 1973). Verma \& 
Prasad (1983) reported that derepression of amino acid transport does not occur in Candida species.

This paper characterizes the proline uptake system in $C$. albicans under a variety of physiological conditions and presents evidence that proline uptake is unaffected at $\mathrm{pH}$ values which inhibit proline-induced germ-tube formation.

\section{METHODS}

Organism. Candida albicans strains (ATCC 10261, A72, 85/031 and a Dunedin hospital isolate) were propagated and maintained on malt extract agar slopes. Dry weight was determined from $\mathrm{OD}_{540}$ in a Shimadzu spectrophotometer with reference to a standard curve.

Culture conditions and germ-tube formation. Yeast cells were grown as shake cultures at $28{ }^{\circ} \mathrm{C}$ in glucose/salts/biotin medium (GSB) (Shepherd \& Sullivan 1976). The nitrogen source was $10 \mathrm{~mm}-\left(\mathrm{NH}_{4}\right)_{2} \mathrm{SO}_{4}$ unless otherwise stated. To prepare cells for optimal germ-tube formation, cultures were starved by aeration in distilled water (Shepherd et al., 1980); germ-tube formation was induced by incubation at $37^{\circ} \mathrm{C}$ in $10 \mathrm{~mm}$ imidazole buffer at a cell concentration of 1.5-2.0 $\times 10^{7}$ cells ml $^{-1}$ with either $2.5 \mathrm{mM}$-GlcNAc (Shepherd et al., 1980) or $10 \mathrm{~mm}$-proline (Dabrowa \& Howard, 1981). Germ-tube formation was assessed by phase-contrast microscopy after dispersal of cell aggregates by mild sonication (10-15 s) in $0.1 \mathrm{M}-\mathrm{NaOH}$ containing $1 \%(\mathrm{w} / \mathrm{v})$ SDS.

Assay of cell aggregation. The yeast cultures of strain ATCC 10261 do not form aggregates of cells, whereas germ-tube formation is accompanied by extensive flocculation. This flocculation is magnesium/calcium dependent and closely parallels germ-tube formation (unpublished results). We have found that an assay of cellcell aggregation can be used routinely as an assessment of germ-tube formation. The degree of flocculation was determined by a sedimentation assay, as follows. A $3 \mathrm{ml}$ sample of a vortexed cell suspension in a plastic cuvette was centrifuged briefly (0-1000 r.p.m. before braking). The $\mathrm{OD}_{540}$ was measured in the cuvette immediately after centrifuging $\left(\mathrm{OD}_{540 \text { initial }}\right)$ and again after resuspending any sedimented cells $\left(\mathrm{OD}_{540 \text { final }}\right)$. The percentage aggregation was calculated from the formula $\left(\mathrm{OD}_{540 \text { final }}-\mathrm{OD}_{540 \text { initial }}\right) / \mathrm{OD}_{540 \text { final }}$. Suspensions of non-flocculant yeast cells gave a background reading of $10 \% \pm 4 \%$.

Measurement of L-proline uptake. A final concentration of $50 \mu \mathrm{M}$ uniformly labelled $\left[{ }^{14} \mathrm{C}\right] p$ poline (Amersham) (specific activity $2.5 \mathrm{mCi} \mathrm{mmol}^{-1}, 92.5 \mathrm{MBq} \mathrm{mmol}^{-1}$ ) was used in the experiments designed to examine the effects of nitrogen source, external $\mathrm{pH}$ and various inhbitors on proline uptake. A yeast cell suspension $(1.0 \mathrm{ml}, 1.5-$ $3.0 \times 10^{7}$ cells $\mathrm{ml}^{-1}$ ) in either $50 \mathrm{~mm}$-imidazole buffer or culture medium was preincubated at the required temperature for $15 \mathrm{~min}$ before addition of $10 \mu 15.0 \mathrm{mM}-\left\{^{14} \mathrm{C}\right]$ proline. At $2 \mathrm{~min}$ intervals $50 \mu \mathrm{l}$ samples were removed and washed on Whatman GFC filters, once with $10 \mathrm{~mm}$ unlabelled proline and three times with distilled water. The filters were dried at $60^{\circ} \mathrm{C}$ and the radioactivity determined by scintillation counting.

Kinetic parameters were determined for different culture conditions by measuring uptake as above for a range of proline concentrations from $50 \mu \mathrm{M}$ to $12.5 \mathrm{mM}$, achieved using three specific activities, $2.5 \mathrm{mCi} \mathrm{mmol}^{-1}$ ( 50 $125 \mu \mathrm{M}), 0.25 \mathrm{mCi} \mathrm{mmol}^{-1}(500-1000 \mu \mathrm{M})$ and $0.025 \mathrm{mCi} \mathrm{mmol}^{-1}(5.0-12.5 \mathrm{~mm})$. At the lowest specific activity 200 or $500 \mu \mathrm{l}$ samples were taken from $2.0 \mathrm{ml}$ cultures. In experiments in which cells were preincubated in proline, cells were washed three times in 2 vols buffer before assay.

For incorporation experiments, $\left[\mathrm{U}^{14} \mathrm{C}\right.$ ]proline $(20 \mu \mathrm{l}, 0.25 \mu \mathrm{Ci}, 1.0 \mu \mathrm{mol})$, was added to a $2.0 \mathrm{ml}$ suspension $\left(1.5 \times 10^{7}\right.$ cells ml $\left.{ }^{-1}\right)$ of starved cells in imidazole buffer at $28^{\circ} \mathrm{C}$. At $30 \mathrm{~min}$ intervals $30 \mu \mathrm{l} \mathrm{samples} \mathrm{were} \mathrm{removed}$ into ice-cold $10 \mathrm{~mm}$-proline for determination of uptake into whole cells; $120 \mu \mathrm{l}$ samples were centrifuged, and after removal of $20 \mu \mathrm{l}$ of the supernatant for assay of remaining radioactivity, the cell suspension was mixed with $100 \mu \mathrm{l}$ ice-cold $20 \% \mathrm{TCA}$ for determination of uptake into TCA-precipitable material (precipitated at $100{ }^{\circ} \mathrm{C}$ for $20 \mathrm{~min}$ ).

Chemicals. Proline, GlcNAc, sarcosine, azetidine-2-carboxylic acid, hydroxyproline and amino acids were obtained from Sigma. All other chemicals were of analytical grade.

\section{RESULTS}

\section{Conditions of germ-tube formation}

The amino acid/salts medium of Lee et al. (1975) is commonly used for induction of germ-tube formation. The individual components of this medium were tested in various combinations for their ability to induce germ-tube formation in C. albicans strains ATCC 10261 and A72 (Table 1). Strain ATCC 10261 will not consistently form germ-tubes after growth in GSB unless it has been starved by aeration in distilled water (Shepherd et al., 1980). In contrast, yeast cells of strain A72 could be used immediately after harvest from GSB and it is referred to as a high responder strain (Mattia et al., 1982). The results demonstrated that of the constituents of Lee's 
Table 1. Germ-tube formation in Lee's medium and in solutions of various amino acids

C. albicans strains A72 and ATCC 10261 were grown as yeast cultures in GSB, washed and resuspended in the test medium at a cell concentration of $1.5-2.0 \times 10^{7}$ cells $\mathrm{ml}^{-1}$. Cells of strain A72 were used immediately after harvesting; ATCC 10261 cells were first starved by aeration. Germ-tube formation was induced and the percentage of germ-tube-forming cells was determined by microscopy as described in Methods. The amino acids were all added at $10 \mathrm{~mm}$ final concentration in $10 \mathrm{~mm}$-imidazole buffer $\mathrm{pH} \mathrm{6.8.} \mathrm{Values} \mathrm{shown} \mathrm{are} \mathrm{the} \mathrm{range} \mathrm{found} \mathrm{for} \mathrm{at} \mathrm{least} \mathrm{three} \mathrm{different} \mathrm{experiments.}$

Medium
Lee's medium
Lee's medium minus glucose
Salts solution of Lee's medium
Amino acid mixture from Lee's medium
Glucose only
Methionine, lysine, phenylalanine
Alanine, lysine, leucine
Proline, alanine
Proline, leucine
Proline, ornithine
Proline, arginine
Ornithine, arginine
Proline
Arginine
Glutamine

Lee's medium

Lee's medium minus glucos

Amino acid mixture from Lee's medium

Glucose only

Methionine, lysine, phenylalanine

Proline, alanine

Proline, leucine

Ornithine, arginine

Arginin

Glutamine

$\begin{array}{cc}\text { Germ-tube formation }(\%) \\ \text { ATCC } 10261 & \text { A72 } \\ >90 & >90 \\ >90 & >90 \\ 0 & 0 \\ >90 & >90 \\ 10-20 & 20-30 \\ 0 & 10-20 \\ >10 & 10-20 \\ 60-80 & >90 \\ 60-80 & >90 \\ >90 & >90 \\ >90 & >90 \\ 50-60 & 50-60 \\ 80-90 & >90 \\ 40-60 & 50-60 \\ 40-60 & 60-80\end{array}$

medium, only proline is able to act as an effective inducer of germ-tube formation. Arginine and glutamine, which are not present in Lee's medium, could also induce germ-tube formation. Ornithine gave a partial induction but no other amino acid tested individually could effect the transformation. No germ-tubes were observed when either D-proline or L-proline immobilized onto agarose (Sigma) was used as inducer.

The time course of germ-tube induction by proline was similar to that observed with GlcNAc (Shepherd et al., 1985). The first protuberances were observed 60-90 min after exposure to the proline at $37^{\circ} \mathrm{C}$. After $150 \mathrm{~min}$ germ-tubes three to five times the length of the mother cell had appeared in more than $90 \%$ of the yeast cells. Usually only one germ-tube was associated with each yeast cell but occasionally $(<5 \%)$ two tubes developed on one yeast cell. Germ-tubes induced by proline were identical in appearance to those produced in GlcNAc. For both proline and GlcNAc a concentration of at least $0.5 \mathrm{~mm}$ was required for optimal germ-tube formation.

Since proline had been shown to be the active component of Lee's medium, it was of interest to determine whether proline-induced morphogenesis was also subject to $\mathrm{pH}$ regulation. Table 2 shows the effect of varying external $\mathrm{pH}$ on morphogenesis. With either proline or GlcNAc as inducer, at $\mathrm{pH} 6.5$ or 5.6 , germ-tube formation was $>80 \%$ and accompanied by extensive cellcell aggregation ( $>85 \%$, see Methods). If the initial pH of the buffering solution (either $10 \mathrm{~mm}-$ imidazole or $50 \mathrm{~mm}$-potassium phthalate) was 5.0 or 4.5 , then proline-induced germ-tube formation was inhibited, whereas GlcNAc induction was unaffected. Similarly, cell-cell aggregation was $<10 \%$ in proline at $\mathrm{pH} 4.5$ but $>80 \%$ in GlcNAc buffered to $\mathrm{pH} 4.5$. The final $\mathrm{pH}$ was determined at the end of each experiment. The data shown are for strain ATCC 10261; similar results were obtained with the other three strains. The following experiments were undertaken to determine whether the observed $\mathrm{pH}$ regulation reflected an inhibition of proline uptake.

\section{Proline uptake by yeast cells}

At $4{ }^{\circ} \mathrm{C}$, in a suspension of starved cells of strain ATCC 10261, no uptake was detectable for a range of proline concentrations $(25$ to $1000 \mu \mathrm{M})$, even when assays were extended up to $1 \mathrm{~h}$. Uptake was, however, observed at $28{ }^{\circ} \mathrm{C}$; at the lowest concentration tested $(25 \mu \mathrm{M})$, the uptake 
Table 2. Effect of $p H$ on GlcNAc-induced and proline-induced germ-tube formation

Starved yeast cells of $C$. albicans ATCC 10261 were washed and resuspended in $5 \mathrm{ml}$ of each buffer at the indicated $\mathrm{nH}$ values at a cell concentration of 1.5-2.0 $\times 10^{7}$ cells $\mathrm{ml}^{-1}$. The cultures were incubated at $37^{\circ} \mathrm{C}$ for $3 \mathrm{~h}$ and germ-tube formation was assayed as described in Methods. The $\mathrm{pH}$ of the supernatants was measured after germ-tube formation. With phthalate buffer it was unchanged; in imidazole buffer the final $\mathrm{pH}$ was $5 \cdot 1$ when the initial $\mathrm{pH}$ was $4 \cdot 5$, and $5 \cdot 8$ when the initial $\mathrm{pH}$ was 6.5 .

\begin{tabular}{cccc}
\multirow{2}{*}{ Buffer } & \multicolumn{3}{c}{$\begin{array}{c}\text { Germ-tube formation } \\
(\%)^{*}\end{array}$} \\
Imitial & $\overbrace{\text { GicNAc }}^{*}$ & Proline \\
Phthalate $(50 \mathrm{mM})$ & $6 \cdot 5$ & 90 & 90 \\
& $4 \cdot 5$ & 90 & $<10$ \\
& $6 \cdot 2$ & 90 & 90 \\
& $5 \cdot 6$ & 90 & 90 \\
& $5 \cdot 0$ & 90 & $<10$ \\
& 4.6 & 90 & 0
\end{tabular}

*Percentage of germ-tube forming cells (standard error $\pm 10 \%$ ).

Table 3. Effect of culture conditions on proline uptake rate

Cultures of $C$. albicans ATCC 10261 yeast cells were harvested after $18 \mathrm{~h}$ growth and proline uptake was determined under the conditions described below. Cell growth, culture incubations and uptake assays were all performed at $28^{\circ} \mathrm{C}$. The growth medium was GSB; for experiments 6 and 7 , bactopeptone was added. The uptake $V_{\max }$ values were calculated from a typical experiment which was repeated three times.

\section{Expt \\ 1 \\ 2 \\ 3 \\ 4 \\ 5 \\ 6 \\ 7}

\section{Culture and assay conditions}

Cells incubated in fresh GSB medium for $3 \mathrm{~h}$ before assay

Cells incubated in fresh nitrogen-free GSB medium for $3 \mathrm{~h}$ before assay

Cells incubated in fresh glucose-free GSB medium for $3 \mathrm{~h}$ before assay

Starved* cells

Starved* cells; incubated for $1 \mathrm{~h}$ with proline $(10 \mathrm{~mm})$ before assay†

Starved* cells

Starved* cells incubated for $1 \mathrm{~h}$ with proline $(10 \mathrm{~mm})$ before assay $\dagger$

$V_{\max }$
[nmol (mg dry wt $)^{-1} \min ^{-1}$ ]
0.43
2.2
0.22
2.87
5.88
6.24
9.18

* Cells were starved by aeration $\left(100 \mathrm{ml} \mathrm{min} \mathrm{min}^{-1}\right.$ per $100 \mathrm{ml}$ cell suspension) in distilled water for $18 \mathrm{~h}$ at room temperature before resuspending and incubation for $1 \mathrm{~h}$ at $28^{\circ} \mathrm{C}$ in imidazole buffer with or without $10 \mathrm{~mm}$ proline.

$\dagger$ Before the uptake assay cells were washed free of proline by centrifugation (three times) and resuspension in buffer.

rate was $0.34 \mathrm{nmol}(\mathrm{mg} \text { dry } w)^{-1} \mathrm{~min}^{-1}$. In addition, prelabelled cells did not lose any significant amount of label when kept on ice for up to $3 \mathrm{~h}$.

At $28^{\circ} \mathrm{C}$, in exponential-phase yeast cells ( $18 \mathrm{~h}$ in GSB), there was a low basal rate of proline uptake $\left[V_{\max } 0.04 \mathrm{nmol}(\mathrm{mg} \text { dry } \mathrm{wt})^{-1} \mathrm{~min}^{-1}\right]$ which increased if proline (final concentration $10 \mathrm{mM}$ ) was added to the culture $1 \mathrm{~h}$ before washing in spent medium and assay [ $V_{\max } 0 \cdot 22 \mathrm{nmol}$ (mg dry wt) $)^{-1} \mathrm{~min}^{-1}$. The $\mathrm{pH}$ of spent medium was low $(3 \cdot 2-3 \cdot 8)$ but proline uptake was unaffected if the $\mathrm{pH}$ was adjusted to that of fresh medium. The effect on uptake of altering the culture conditions is shown in Table 3. Transferring the cells to fresh medium increased uptake approximately ten-fold and this was increased a further five-fold if the fresh medium did not contain a nitrogen source. Omitting glucose from the medium did not result in an increase in uptake. An increased rate of uptake was also found if cells were starved of both carbon and nitrogen reserves by aeration in distilled water (Table 3, experiment 4); this was also observed for similarly treated cells which had been grown in the nitrogen-rich medium of GSB 


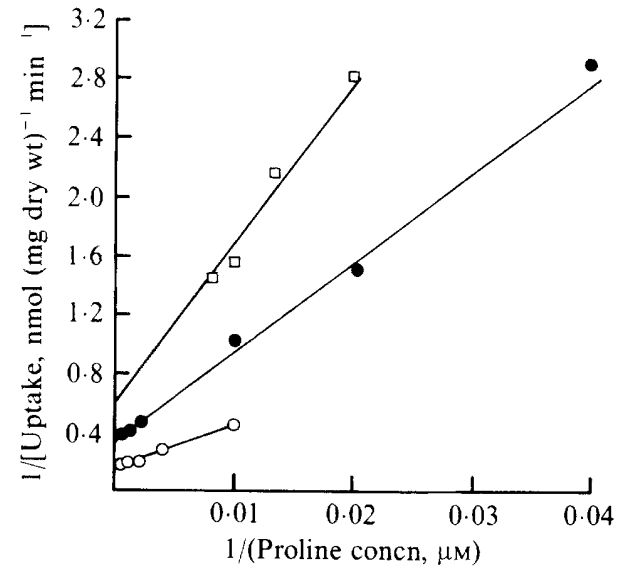

Fig. 1

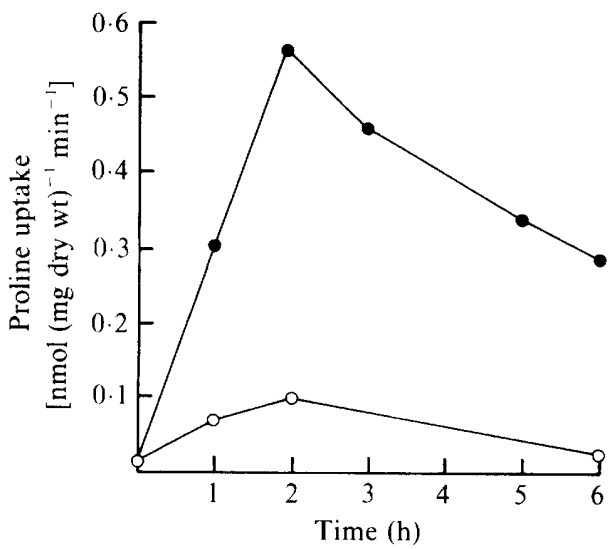

Fig. 2

Fig. 1. Proline uptake by $C$. albicans ATCC 10261. Proline uptake at $28{ }^{\circ} \mathrm{C}$ was determined for a range of proline concentrations in yeast cells cultured under the following conditions: starved by aeration and preincubated for $1 \mathrm{~h}$ in buffer $(O)$; starved by aeration and preincubated for $1 \mathrm{~h}$ in $10 \mathrm{~mm}$-proline $(\mathrm{O})$; preincubated for $6 \mathrm{~h}$ and assayed in GSB without ammonium sulphate ( $\square$ ).

Fig. 2. Derepression of proline uptake by $C$. albicans ATCC 10261 . Yeast cells from an $18 \mathrm{~h}$ culture $\left(28^{\circ} \mathrm{C}\right)$ in GSB were centrifuged and resuspended in either $\mathrm{NH}_{4}^{+-}$-free medium $(\mathcal{O})$ or fresh complete medium $(O)$ and reincubated at $28^{\circ} \mathrm{C}$. At the times indicated $1 \mathrm{ml}$ samples were removed and the proline uptake rate was determined at $28{ }^{\circ} \mathrm{C}$ as described in Methods.

supplemented with $1 \%(\mathrm{w} / \mathrm{v})$ bactopeptone (Table 3, experiment 6$)$. In both cases a still higher uptake rate was observed after preincubation with proline (Table 3, experiments 5 and 7). The maximum uptake rate was achieved in cells which had been grown in nitrogen-rich medium, starved by aeration and then preincubated with proline for $1 \mathrm{~h}$.

Double reciprocal plots of proline uptake for cells produced under a variety of conditions are shown in Fig. 1 (concentration range $50 \mu \mathrm{M}$ to $2.0 \mathrm{mM}$ ). The $V_{\max }$ varied, and the $K_{\mathrm{m}}$, calculated by a direct linear plot (Eisenthal \& Cornish-Bowden, 1974), had a mean value of $179 \mu \mathrm{M}$ (SD 12.7). Data for cultures containing ammonium ions could not be shown on the scale of Fig. 1 but the same $K_{\mathrm{m}}$ was obtained and the $V_{\max }$ values are given in Table 3 or in the text. To investigate the possibility that another permease operates at high proline concentrations, uptake rates were determined over the concentration range $2.0-12.5 \mathrm{~mm}$. For starved cells, with or without proline preincubation, there was no significant increase in the proline uptake rate. Cells cultured in the presence of ammonium ions were not tested at these concentrations as the uptake rates at the lower specific activities were too low.

The results in Table 3 suggested that the proline uptake system in C. albicans is subject to ammonium repression. Fig. 2 shows the time course of derepression of proline uptake following removal of the nitrogen source. In cells transferred from an $18 \mathrm{~h}$ culture to fresh GSB the uptake rate increased, but the increase was five- to six-fold higher when the fresh medium lacked ammonium ions. A maximum rate was obtained within $2 \mathrm{~h}$ of transfer. Both ammonium ions and glutamine were found to mediate repression of proline uptake; the uptake rate for cells transferred from GSB to GSB containing $10 \mathrm{~mm}$-glutamine as the nitrogen source was sevenfold lower (at $2 \mathrm{~h}$ ) than that for cells transferred to nitrogen-free GSB. The repressive effect of ammonium ions or glutamine was not due to direct competition for the permease, since neither ammonium sulphate $(10 \mathrm{~mm})$ nor glutamine $(5 \mathrm{~mm})$ inhibited proline uptake when added to derepressed cultures immediately before assay. However, $13 \mathrm{~min}$ after the addition of ammonium sulphate or glutamine, proline uptake was reduced from 0.29 to 0.07 and from 0.25 to $0.13 \mathrm{nmol}(\mathrm{mg} \text { dry } \mathrm{wt})^{-1} \mathrm{~min}^{-1}$, respectively. Derepression also occurred in cells transferred from GSB to medium lacking both nitrogen and glucose (results not shown) and in cultures starved by aeration in distilled water (Table 3); however, in these cultures proline uptake could 
not be repressed by the subsequent addition of ammonium sulphate. Cells transferred to GSB containing either alanine (doubling time $2.5 \mathrm{~h}$ ) or leucine (doubling time $6.0 \mathrm{~h}$ ) as the sole nitrogen source were derepressed for proline uptake [uptake rates 0.3 and $0.5 \mathrm{nmol}(\mathrm{mg}$ dry weight $)^{-1} \min ^{-1}$ respectively after $6 \mathrm{~h}$, proline concentration $\left.50 \mu \mathrm{M}\right]$.

\section{Specificity of the proline uptake system}

A number of analogues of proline and other compounds were tested for their effect on proline uptake, germ-tube formation and cell-cell aggregation. Proline uptake was assayed as described in Methods, the final concentration of proline was $50 \mu \mathrm{M}$ and analogues or other compounds were added to a final concentration of $1.0 \mathrm{~mm} 5 \mathrm{~min}$ before addition of $\left[{ }^{14} \mathrm{C}\right]$ proline. D-Proline, sarcosine and azetidine-2-carboxylic acid all inhibited proline uptake to a similar degree $(60-70 \%)$, but of these compounds only sarcosine and azetidine-2-carboxylic acid (10 mM) completely inhibited germ-tube formation and cell-cell aggregation induced by L-proline (1.0 mM). Azetidine-2-carboxylic acid, at concentrations greater than $0.1 \mathrm{~mm}$, also inhibited germ-tube induction by GlcNAc, but sarcosine $(10 \mathrm{~mm})$ had no effect. Canavanine, an analogue of arginine, also inhibited both GlcNAc- and proline-induced germ-tube formation. Glutamine, glycine, alanine, histidine, arginine, hydroxy-L-proline and ammonium ions (as chloride or sulphate) had no significant effect on proline uptake, indicating the specificity of the permease.

\section{Effect of $\mathrm{pH}$ on uptake and incorporation of $\left[\mathrm{U}^{14} \mathrm{C}\right]$ proline}

In two different buffer systems (imidazole and phthalate), uptake at $\mathrm{pH} 4.5$ was similar to that at $\mathrm{pH} 6.5$, irrespective of temperature and preincubation conditions (Table 4). Fig. 3 shows, for both $\mathrm{pH}$ values, the uptake of proline into whole cells, the incorporation of radioactivity into TCA-precipitable material, and the concomitant loss of radioactivity from the medium. This experiment confirms that lowering the $\mathrm{pH}$ does not reduce the uptake of proline into C. albicans, nor the intracellular incorporation of the radioactive label into macromolecules. Indeed there was slightly more incorporation in the cultures at $\mathrm{pH} 4.5$ than in those at $\mathrm{pH} 6.5$. At $\mathrm{pH} 4.5$ approximately $25 \%$ of the radioactivity was lost from the cultures, presumably as carbon dioxide. A similar pattern of incorporation was observed at both $\mathrm{pH}$ values when the proline concentration was increased to $2 \mathrm{~mm}$. However, after $3 \mathrm{~h}$ only $20 \%$ of the radioactivity had been removed from the medium.

\section{Nitrogen status and germ-tube formation}

It has been previously observed that in some strains of $C$. albicans, starvation is a necessary prerequisite for germ-tube formation (Shepherd et al., 1980), and exponentially growing cells of strain ATCC 10261 do not reproducibly form germ-tubes when transferred directly to $37^{\circ} \mathrm{C}$ with an inducer. However, when cells harvested at mid-exponential phase were first incubated in glucose-free medium for at least $3 \mathrm{~h}$, germ-tube formation was consistently induced in $>90 \%$ of the cells (Fig. 4). In contrast, cells starved of nitrogen in the presence of glucose for $3 \mathrm{~h}$ or more were not competent to undergo morphogenesis. The results shown are for the GlcNAc induction system and strain ATCC 10261. Similar results were obtained when proline was used as inducer, and nitrogen-starved cultures of the three other strains used in this study were also unable to form germ-tubes in the presence of either inducer. The ratio of viable count to $\mathrm{OD}_{540}$ was unchanged after $24 \mathrm{~h}$ of either nitrogen or glucose starvation. If proline, glutamine, asparagine, arginine or ornithine replaced ammonium ions in the medium, cells remained competent to form germ-tubes. In contrast, cells transferred to medium containing leucine, alanine or phenylalanine as the nitrogen source did not, although these compounds can act as a sole source of nitrogen for growth. Nitrogen-starved cells regained the capacity to form germ-tubes if they were transferred to GSB medium containing any one of ammonium ions, proline, arginine, ornithine, glutamine or asparagine as the nitrogen source for at least $3 \mathrm{~h}$. Nitrogen-starved cells subjected to glucose or glucose/nitrogen starvation remained refractory for germ-tube formation. These results are summarized in Fig. 5. Batch cultures grown in glucose-limiting conditions (GSB in which the glucose concentration was reduced 10-fold) produced cells 


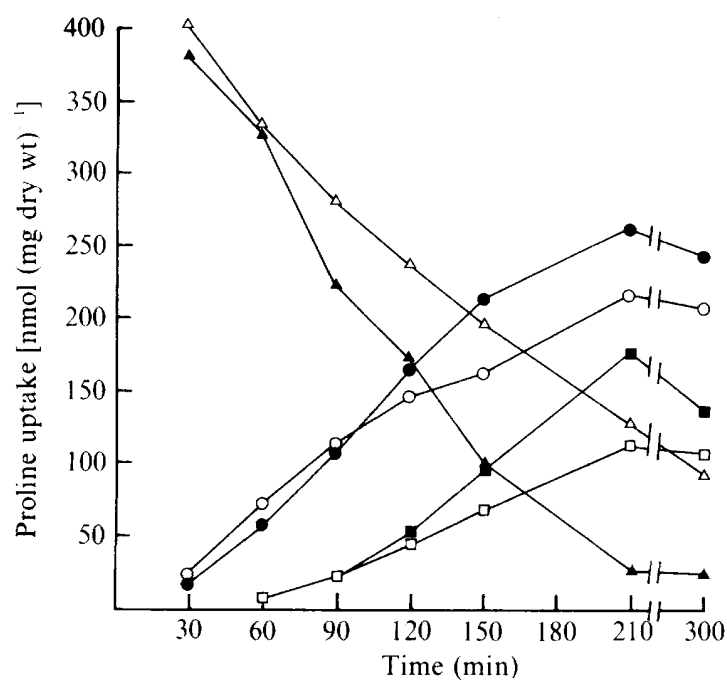

Fig. 3

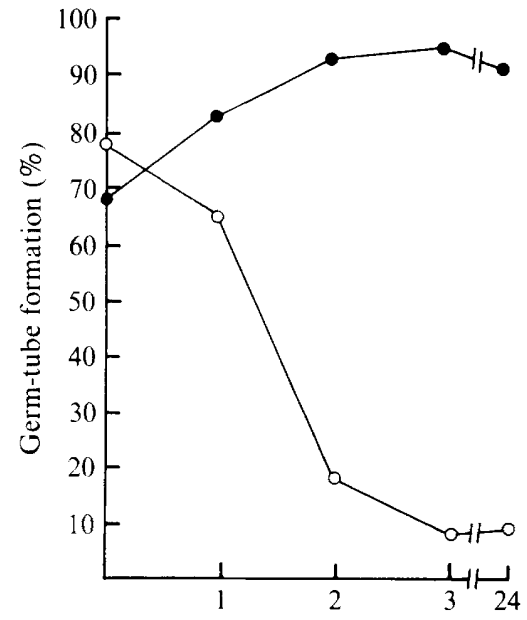

Period of nitrogen or glucose deprivation $(\mathrm{h})$

Fig. 4

Fig. 3. Effect of $\mathrm{pH}$ on the incorporation of $\left[{ }^{14} \mathrm{C}\right]$ proline into whole cells and TCA-precipitable material. Starved yeast cells of $C$. albicans ATCC 10261 were resuspended in $2.0 \mathrm{ml}$ imidazole buffer $(10 \mathrm{~mm})$. The uptake of $\left[{ }^{14} \mathrm{C}\right]$ proline into whole cells and TCA-precipitable material, and the disappearance of radiolabel from the medium, were determined as described in Methods. $O$, Uptake into whole cells, at pH 6.5 (O) and at pH 4.5 (O); $\square, \square$, uptake into TCA-precipitable material, at pH $6.5(\square)$ and at $\mathrm{pH} 4.5(\square) ; \triangle$, $\boldsymbol{\Delta}$, radioactivity in culture supernatant, at pH $6.5(\triangle)$ and at $\mathrm{pH} 4.5(\mathbf{\Lambda})$.

Fig. 4. Effect of nitrogen and glucose limitation on germ-tube formation. Cells of C. albicans ATCC 10261 were harvested ty centrifugation from $18 \mathrm{~h}$ cultures in GSB, transferred to GSB lacking either glucose $(O)$ or ammonium ions $(O)$ and incubated at $28^{\circ} \mathrm{C}$. Samples $(1.0 \mathrm{ml})$ were taken at $1 \mathrm{~h}$ intervals and washed cells assayed for the ability to form germ-tubes in imidazole buffer with GlcNAc at $37^{\circ} \mathrm{C}$ at cell concentrations of $1.5-2.0 \times 10^{7}$ cells $\mathrm{ml}^{-1}$.

Table 4. Effect of pH on proline uptake

Suspensions of $C$. albicans ATCC 10261 cells that had been starved by aeration were washed and resuspended in either imidazole $(10 \mathrm{~mm})$ or phthalate $(5.0 \mathrm{mM})$ buffer at $\mathrm{pH} 4.5$ or $\mathrm{pH} 6.5$. The rate of proline uptake was measured as described in Methods.

$\begin{array}{cccc}\text { Buffer } & \begin{array}{c}\text { Temperature } \\ \text { of assay }\left({ }^{\circ} \mathrm{C}\right)\end{array} & \overbrace{\mathrm{pH} 4.5}^{\begin{array}{c}\text { Uptake rate } \\ \text { [nmol (mg dry wt })^{-1} \\ \text { min }{ }^{-1} \text { ] }\end{array}} & \mathrm{pH} \mathrm{6.5} \\ \text { Imidazole } & 28 & 0.36 & 0.44 \\ \text { Imidazole } & 37 & 0.95 & 0.98 \\ \text { Phthalate } & 28 & 0.44 & 0.46 \\ \text { Phthalate } & 37 & 0.84 & 0.75\end{array}$

competent to form germ-tubes whereas cells cultured in nitrogen-limiting conditions (GSB in which the ammonium sulphate concentration was reduced 10-fold) to stationary phase were not.

\section{DISCUSSION}

Proline was found to be the sole effector of morphogenesis in Lee's medium; the carbon source (glucose), and vitamin (biotin), were only required to maintain growth (Table 1). The observations of Pollack \& Hashimoto (1987), who report proline-induced germ-tube formation 


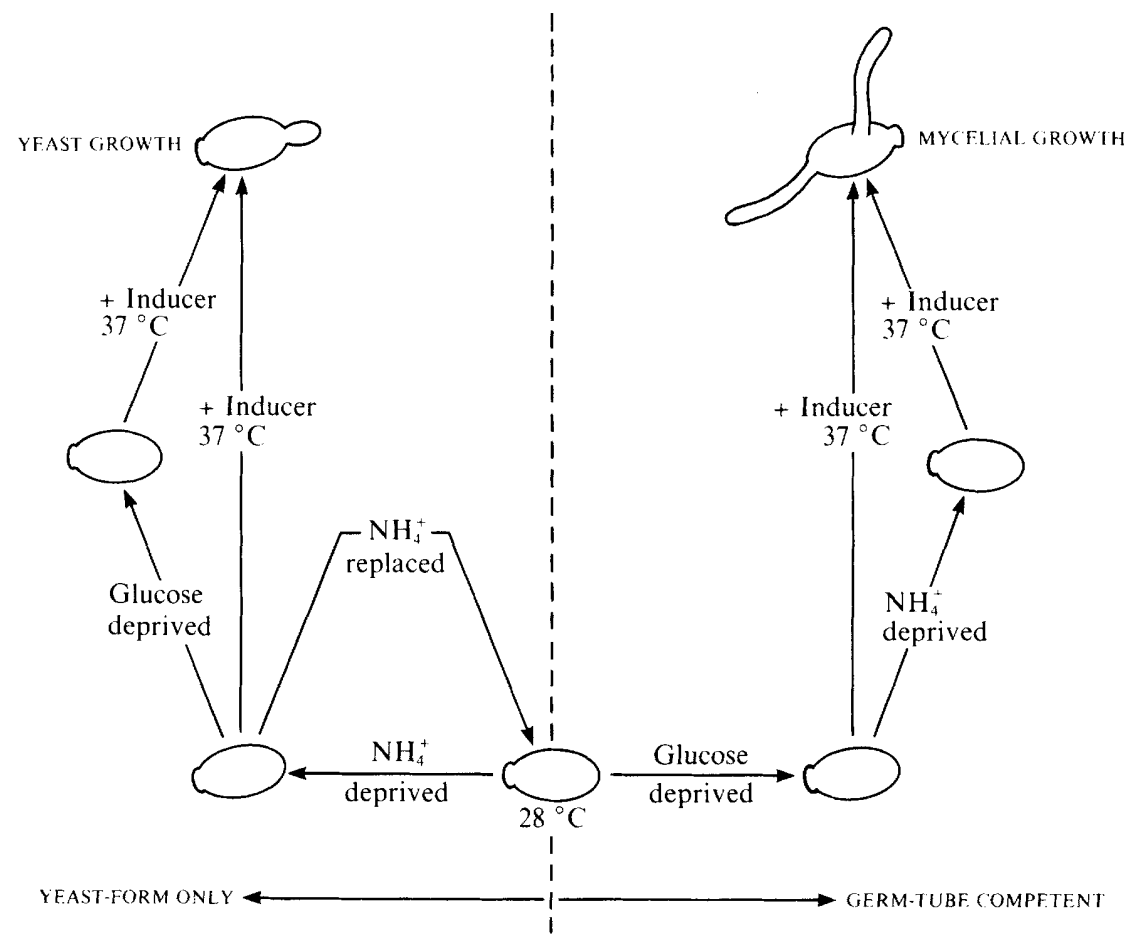

Fig. 5. Schematic representation of the relationship between the nutritional status of the cells and morphogenesis.

at $\mathrm{pH} 3.7$, are difficult to reconcile with our data and those of Mitchell \& Soll (1979). Morphogenesis in Lee's medium is pH dependent (Mitchell \& Soll, 1979). We have shown a similar sensitivity to $\mathrm{pH}$ for germ-tube formation in a simple buffered proline solution, whereas GlcNAc induction was unaffected. The proline transport system was examined to determine whether this differential sensitivity resulted from an inhibition of proline uptake at low $\mathrm{pH}$.

Two characteristics of the proline transport system in $C$. albicans suggest that regulation of proline uptake is not related to morphogenesis. Firstly, uptake is unaffected at a $\mathrm{pH}$ inhibitory of germ-tube formation (Table 4, Fig. 3). Secondly, although uptake is relatively high $\left[V_{\max }\right.$ $\left.2.2 \mathrm{nmol}(\mathrm{mg} \text { dry weight })^{-1} \mathrm{~min}^{-1}\right]$ in cultures starved of nitrogen in the presence of glucose (Table 3), these cells did not form germ-tubes in the presence of either inducer (Fig. 4). Thus, although we have confirmed that L-proline can act, like GIcNAc (Simonetti et al., 1974), as a specific inducer of germ-tube formation (Dabrowa et al., 1976), uptake of proline does not necessarily promote the transition from the yeast to the mycelial form. Mattia et al. (1982) reported that responsiveness to germ-tube induction was not correlated with the capacity to take up and metabolize GlcNAc. Furthermore, GlcNAc immobilized onto agarose can act as an inducer for germ-tube formation in C. albicans (Shepherd \& Sullivan, 1983). We found immobilized proline to be ineffective, but the possibility that proline acts as an external effector of morphogenesis cannot be excluded as GlcNAc-agarose is linked via the C6 of the sugar moiety, whereas proline is linked to agarose via the - NH group. The secondary amine sarcosine inhibited proline uptake and proline-induced germ-tube formation, but had no effect on GlcNAc induction of morphogenesis. Again, the possibility of proline action being extracellular cannot be excluded although any receptor system would be separate from that for GlcNAc. By contrast, another proline analogue, azetidine-2-carboxylic acid, inhibited both proline- and GlcNAc-induced germ-tube formation and cell-cell aggregation. Azetidine-2-carboxylic acid, like the arginine analogue canavanine, causes synthesis of defective proteins (Peterson \& Fowden, 1963). Previous studies have shown that de novo protein synthesis is critical during 
germ-tube formation (Shepherd et al., 1980; Sullivan et al., 1983), and azetidine-2-carboxylic acid may be incorporated into germ-tube-specific proteins rendering them defective.

Characterization of the proline uptake system showed it to be constitutive, as found by Dabrowa \& Howard (1981) and Jayakumar et al. (1979), specific, confirming the results of Dabrowa \& Howard (1981), and partially inducible in that preincubation in proline increased uptake, a finding also reported by Jayakumar et al. (1979). We also found that proline uptake was subject to ammonium repression; removal of nitrogen from the medium resulted in an increase of the proline uptake rate in both the presence and absence of glucose. Verma \& Prasad (1983) found no evidence for ammonium repression of the uptake of a number of amino acids or the imino acid proline in C. albicans, but it has been demonstrated in S. chevalieri (Kuznar et al., 1973), S. cerevisiae (Lasko \& Brandriss, 1981) and Aspergillus nidulans (Arst et al., 1980). The difference in uptake rates between yeast and mycelial cells found by Dabrowa \& Howard (1981) may have reflected derepression occurring in the mycelial cultures before the uptake determination.

Considerable variation was observed in the uptake rate under different culture conditions, but over a wide range of proline concentrations $(50 \mu \mathrm{M}$ to $12.5 \mathrm{mM})$, only one uptake system was detected, with a $K_{\mathrm{m}}$ of $179 \mu \mathrm{M}$. We could not detect uptake by either diffusion, as suggested by Dabrowa \& Howard (1981), or the operation of a separate low-affinity permease at high external concentrations as shown for $S$. cerevisiae (Lasco \& Brandriss, 1981).

The observation that either the amino sugar GlcNAc or the imino acid L-proline is sufficient to effect morphogenesis led us to examine the role of the nitrogen status of the cell in the yeast-tomycelial transformation. Fig. 5 summarizes the effect of altering nitrogen status on the competence of yeast cells to form germ-tubes. Essentially, limitation of the carbon source for strain ATCC 10261 produced cells competent for morphogenesis, but in the presence of glucose, removal of the nitrogen source reversibly abolished the ability of cells to form mycelial elements for the four strains tested. In batch culture, the ability of stationary-phase cells to undergo morphogenesis depended on the nature of the limiting nutrient. Cells limited for nitrogen were unable to form germ-tubes whereas with stationary-phase cells from glucose-limited cultures germ-tubes could be induced by either GlcNAc or proline. This was confirmed using nitrogenlimited cells from chemostat cultures (A. Collings \& A. R. Holmes, unpublished results). Several workers have observed that mycelial induction is favoured by using stationary phase cells (Chaffin \& Sogin, 1976; Soll \& Bedell, 1978; Shepherd et al., 1980), which under the conditions used would have been glucose limited. It has been postulated that germ-tube formation occurs only when the cells are blocked at an early stage (G1) of the cell cycle (Soll \& Bedell, 1978). This was challenged by Mattia \& Cassone (1979), who demonstrated that in the presence of a suitable inducer cells at any stage of growth are able to form germ-tubes at $37^{\circ} \mathrm{C}$. The present study would suggest that it is the nutritional status of the cells rather than the stage of the cell cycle that determines the competence to undergo morphogenesis.

It is tempting to speculate that the two known simple chemical inducers of morphogenesis, proline and GlcNAc, act in a similar manner via catabolism to a common intermediate. Proline is catabolized via glutamate to 2-oxoglutarate (Land et al., 1975). During GlcNAc metabolism, glutamine is produced (Gopal et al., 1982), from which 2-oxoglutarate could be formed, via glutamate. Glutamate synthase activity has been demonstrated in $S$. cerevisiae (Roon et al., 1974). The amino acids, such as arginine, that can give partial induction of germ-tube formation and which can also reverse the inhibitory effects of nitrogen starvation on morphogenesis, are also metabolized via 2-oxoglutarate. During nitrogen starvation, in spite of an increased uptake of proline, there is no induction of germ-tube formation. Using low cell concentrations, Pollack \& Hashimoto (1987) reported that glucose can inhibit germ-tube formation, and suggested that the action of glucose is mediated by catabolite repression. We speculate that under conditions of nitrogen starvation, which may produce a glucose repression effect, yeast morphology is favoured and for morphogenesis to occur the tricarboxylic acid cycle must be stimulated. This would result in an increased production of $\mathrm{CO}_{2}$, and recently, Sims (1986) has reported that elevated $\mathrm{CO}_{2}$ partial pressure enhances the mycelial growth of $C$. albicans at the normally suboptimal temperature of $30^{\circ} \mathrm{C}$. 
This study has shown that $\mathrm{pH}$-regulated morphogenesis is not the result of modulation of the inducer uptake. We have demonstrated that the nutritional status of the cell is a critical factor in determining whether cells of $C$. albicans will undergo morphogenesis and suggest that proline and GlcNAc may act in a similar manner through a common intermediate of catabolism.

This work was supported by grants from the Medical Research Council (MRC) of New Zealand.

\section{REFERENCES}

ARST, H. N., JR, MacDonald, D. W. \& Jones, S. A. (1980). Regulation of proline transport in Aspergillus nidulans. Journal of General Microbiology 116, 285294.

Chaffin, W. L. \& Sogin, S. J. (1976). Germ-tube formation from zonal rotor fractions of Candida albicans. Journal of Bacteriology 126, 771-776.

Dabrowa, N. \& Howard, D. H. (1981). Proline uptake in Candida albicans. Journal of General Microbiology 127, 391-397.

Dabrowa, N., TaXer, S. S. S. \& Howard, D. H (1976). Germination of Candida albicans induced by proline. Infection and Immunity 13, 830-835.

EISENTHAL, R. \& CORNISH-BOWDEN, A. (1974). The direct linear plot. Biochemical Journal 139, 715-720.

Gopal, P., Sullivan, P. A. \& Shepherd, M. G. (1982). Enzymes of $N$-acetylglucosamine metabolism during germ-tube formation in Candida albicans. Journal of General Microbiology 128, 2319-2326.

Herman, M. A. \& Soll, D. R. (1984). A comparison of volume growth during bud and mycelium formation in Candida albicans: a single cell analysis. Journal of General Microbiology 130, 2219-2228.

Jayakumar, A., Singh, M. \& Prasad, R. (1979). An inducible proline transport system in Candida albicans. Biochimica et biophysica acta 556, 144-150.

KuZNAR, J., SCHWENCKE, J. \& MAGAÑA-SCHWENCKe, N. (1973). Sarcosine and imino acid uptake in Saccharomyces chevalieri. Derepression by nitrogen starvation. Biochimica et biophysica acta 318, 273280.

Land, G. A., McDonald, W. C., Stjernholm, R. L. \& Friedman, L. (1975). Factors affecting filamentation in Candida albicans: relationship of the uptake and distribution of proline to morphogenesis. Infection and Immunity 11, 1014-1023.

Lasko, P. F. \& Brandriss, M. C. (1981). Proline transport in Saccharomyces cerevisiae. Journal of Bacteriology 148, 241-247.

Lee, K. L., Buckley, H. R. \& Campbell, C. C. (1975). An amino acid liquid synthetic medium for the development of mycelial and yeast forms of Candida albicans. Sabouraudia 13, 148-153.

MaGaÑa-SCHWENCKe, N., KuZnaR, J. \& SCHWENCKe, J. (1973). Imino acid transport in yeast : the uptake of sarcosine. Biochimica et biophysica acta 318, 281-288.

MATTIA, E. \& CASSONE, A. (1979). Inducibility of germtube formation in Candida albicans at different phases of yeast growth. Journal of General Microbiology 113, 439-442.

Mattia, E., Carruba, G., Angiolella, L. \& CasSONE, A . (1982). Induction of germ tube formation by $N$-acetyl-D-glucosamine in Candida albicans: uptake of inducer and germinative response. Journal of Bacteriology 152, 555-562.

MitChell, L. H. \& Soll, D. R. (1979). Commitment to germ tube or bud formation during release from stationary phase in Candida albicans. Experimental Cell Research 120, 167-179.

Peterson, P. J. \& Fowden, L. (1963). Different specificities of proline-activating enzymes from some plant species. Nature, London 200, 148-151.

Pollack, P. J. \& Hashimoto, T. (1987). The role of glucose in the $\mathrm{pH}$ regulation of germ-tube formation in Candida albicans. Journal of General Microbiology 133, 415-425.

RoON, R. J., Even, H. L. \& Larimore, F. (1974). Glutamate synthase: properties of the reduced nicotinamide adenine dinucleotide-dependent enzyme from Saccharomyces cerevisiae. Journal of Bacteriology 118, 89-95.

ShePherd, M. G. \& Sullivan, P. A. (1976). The production and growth characteristics of yeast and mycelial forms of Candida albicans in continuous culture. Journal of General Microbiology 93, 361-370.

Shepherd, M. G. \& Sullivan, P. A. (1983). Candida albicans germ-tube formation with immobilised GlcNAc. FEMS Microbiology Letters 17, 167-170.

Shepherd, M. G., ChIEW, Y. Y., Ram, S. P. \& Sullivan, P. A. (1980). Germ-tube induction in Candida albicans. Canadian Journal of Microbiology 26, 21-26.

Shepherd, M. G., Poulter, R. T. M. \& Sullivan, P. A. (1985). Candida albicans: biology, genetics, and pathogenicity. Annual Review of Microbiology 39, 579-614.

Simonetti, N., Strippoli, V. \& Cassone, A. (1974). Yeast-mycelial conversion induced by $N$-acetyl-Dglucosamine in Candida albicans. Nature, London 250, 344-346.

Sims, W. (1986). Effect of carbon dioxide on the growth and form of Candida albicans. Journal of Medical Mycology 22, 203-208.

Soll, D. R. \& BeDELl, G. W. (1978). Bud formation and the inducibility of pseudo-mycelium outgrowth during release from stationary phase in Candida albicans. Journal of General Microbiology 108, 173180.

Sullivan, P. A., Chiew, Y. Y., Molloy, C., Templeton, M. D. \& Shepherd, M. G. (1983). An analysis of the metabolism and cell wall composition of Candida albicans during germ-tube formation Canadian Journal of Microbiology 29, 1514-1525.

Verma, R. S. \& Prasad, R. (1983). Absence of derepression of amino acids transport in Candida. Biochemistry International 7, 707-717. 